\begin{tabular}{c} 
Brazilian Journal \\
of Chemical \\
Engineering \\
\hline
\end{tabular}

ISSN 0104-6632 Printed in Brazil

Vol. 21, No. 02 pp. 155 - 164, April - June 2004

\title{
EXPRESSION OF Pisum sativum DEFENSIN 1 (Psd1) IN SHAKING FLASKS AND BIOREACTOR CULTIVATIONS OF RECOMBINANT Pichia pastoris AT DIFFERENT pHs
}

\author{
A. L. Larentis ${ }^{1,2^{*}}$, M. S. Almeida ${ }^{1}$, K. M. S. Cabral ${ }^{1}$, L. N. Medeiros ${ }^{1}$, \\ E. Kurtenbach ${ }^{1}$ and M. A. Z. Coelho ${ }^{2}$ \\ ${ }^{1}$ Departamento de Bioquímica Médica, Instituto de Ciências Biomédicas, \\ Universidade Federal do Rio de Janeiro, Rio de Janeiro - RJ, Brazil. \\ ${ }^{2}$ Departamento de Engenharia Bioquímica, Escola de Química, Universidade Federal do Rio de Janeiro, \\ COPPE, Campus do Fundão, Centro de Tecnologia, Bloco E, Lab.113, Phone +(55) (21) 2562-7622, \\ Fax +(55)(21) 2562-7567, CEP 21949-900, Rio de Janeiro - RJ, Brazil. \\ E-mail: alice@eq.ufrj.br
}

(Received: February 13, 2003 ; Accepted: November 27, 2003)

\begin{abstract}
The methylotrophic yeast Pichia pastoris was used to produce the recombinant Pisum sativum defensin ( $\mathrm{r} P s \mathrm{~d} 1)$, a small peptide from pea seeds that has a high level of antifungal activity. The plasmid $\mathrm{r} P s \mathrm{~d} 1 / \mathrm{pPIC} 9$ was integrated into the yeast genome and methanol was used to induce expression and secretion of the recombinant $P s \mathrm{~d} 1$, at $30^{\circ} \mathrm{C}$ in a fed-batch mode. The effects of different $\mathrm{pH}$ conditions and process scale-up were evaluated using a Monod-type model where dissolved oxygen was considered the limiting substrate. Parameter estimation showed that the process could be improved by expressing $\mathrm{r} P s \mathrm{~d} 1$ in a $1000 \mathrm{~mL}$ bioreactor at $\mathrm{pH} 4$. Structural and functional analyses revealed that the recombinant $P s \mathrm{~d} 1$ is very similar to the native one.

Keywords: Pichia pastoris, Pisum sativum Defensin 1, recombinant DNA, fed-batch, modeling, $\mathrm{pH}$.
\end{abstract}

\section{INTRODUCTION}

Pichia pastoris is a methylotrophic yeast employed as the heterologous expression system for many different proteins (Romanos, 1995; Chen et al., 1997; Cereghino and Cregg, 2000). One of the most important system characteristics is the yeast's ability to grow to high biomass concentrations and to secrete high concentrations of proteins (Romanos, 1995; Chiruvolu et al., 1997). Moreover, recombinant Pichia pastoris is genetically stable (Romanos, 1995; Cereghino and Cregg, 2000) and has a cell apparatus that allows post-translational modifications, such as disulfide bond formation and glycosylation (Chen et al., 1997; Cereghino and
Cregg, 2000; Files et al., 2001). Nevertheless, this expression system may present some problems, such as the proteolysis of secreted proteins and the inefficient secretion of complex heterologous proteins (Romanos, 1995), even though these are not well understood mechanisms.

The ability of Pichia pastoris to use methanol as a source of carbon and energy is credited to the action/presence of the enzyme alcohol oxidase (AOX), which catalyzes the methanol oxidation to formaldehyde and hydrogen peroxide (Chen et al., 1997). This enzyme is responsible for $35 \%$ of the total proteins found in Pichia pastoris soluble extracts, when the yeast is cultivated with methanol at growth-limiting rates, i.e., when methanol is added

*To whom correspondence should be addressed 
in limited amounts, suitable to induce the alcohol oxidase promoter and to avoid inhibition (Chen et al., 1997; Sreekrishna et al., 1997; Cereghino and Cregg, 2000). Two genes, AOX1 and AOX2, codify alcohol oxidase, and AOX1 expression is responsible for the majority of the enzyme activity. Furthermore, both gene regulation sequences are activated by methanol, but repressed by glucose, glycerol and ethanol (Sreekrishna et al., 1997; Minning et al., 2001; Files et al., 2001).

The genetic transformation method used to clone Pichia pastoris determines the recombinant yeast phenotype produced. In order to maximize stability of the strain and avoid heterologous gene loss, the expression vector is integrated into the yeast genome (Sreekrishna et al., 1997; Chiruvolu et al., 1997; Cereghino and Cregg, 2000). This integration can be carried out by vector linearization on the marker gene or in the promoter by means of suitable restriction enzyme treatment. If integration does not occur on the AOX gene, the strain generated is called Mut $^{+}$and it is able to metabolize methanol efficiently at high growth rates $\left(\mu=0.14 \mathrm{~h}^{-1}\right)$. Conversely, when integration is directed to the AOX1 locus, the resulting phenotype is Mut. This strain has the inactivated AOX1 gene and is able to grow more slowly $\left(\mu=0.01-0.04 \mathrm{~h}^{-1}\right)$ in methanol (Brierley et al., 1990).

The reportedly facile Pichia pastoris heterologous protein production scale-up from shaking flasks to high cell concentrations in bioreactors is an advantageous characteristic of this expression system (Cereghino and Cregg, 2000). The use of Pichia pastoris as an expression system in bioreactors has been described for production of several proteins, such as hepatitis B surface antigen (Cregg et al., 1987), lysozyme (Brierley et al., 1990), glycolate oxidase and catalase (Payne et al., 1995 and 1997), thrombomodulin fragment (Chen et al., 1997), $\beta$-galactosidase (Chiruvolu et al., 1997), Ancylostoma caninum anticoagulant peptide (Inan et al., 1999), human $\alpha$-galactosidase A (Chen et al., 2000), lipase (Minning et al., 2001), porcine folliclestimulating hormone (Boze et al., 2001), protease inhibitor cystatin C (Files et al., 2001), yielding from hundreds of milligrams to a gram per liter, in timeconsuming processes of up to $200 \mathrm{~h}$. Many of these proteins are currently used as vaccines and human pharmaceuticals, as Pichia pastoris does not produce endotoxins and the growth on medium containing methanol helps to avoid contamination by microorganisms (Cregg et al., 1987; Chen et al., 1997; Cereghino and Cregg, 2000). According to those reports, obtaining a high yield of foreign protein expression seems to depend on rigorous control of methanol level and a high level of maintenance of dissolved oxygen on growth medium. Furthermore excess methanol can be toxic to the cell and drastically reduce promoter AOX activity, eventually leading to cell death (Brierley et al., 1990; Chiruvolu et al., 1997; Minning et al., 2001). In addition, methanol metabolism requires a high concentration of oxygen and the heterologous gene expression is negatively affected by limiting oxygen (Chen et al., 1997; Files et al., 2001). These high yields are also related to fed-batch operations in bioreactors, overcoming substrate or product inhibition and catabolite repression, for instance (Chen et al., 1997).

Pichia pastoris was used as host for a $\sim 5 \mathrm{kDa}$ peptide expression with plant defensin properties, which had previously been extracted from pea seeds (Pisum sativum) and named Psd 1 by Almeida et al. (2000). Defensins are a 45-54 amino-acid protein group rich in cysteine, which form intramolecular disulfide bonds. Studying this protein is of biotechnological interest, as it has high inhibitory activity against several microorganisms, mainly phytopathogenic fungi. The extraction of defensin from pea seeds is laborious and the yield is low (Almeida et al., 2000), thereby encouraging the application of recombinant DNA tools to produce high levels of peptide using Pichia pastoris as an efficient heterologous expression system. In this work, the rPsd1 expression level was evaluated under different $\mathrm{pH}$ and scale-up conditions. Results were analyzed by modeling and employed aiming at improving protein production.

\section{EXPERIMENTAL SECTION}

\section{Cloning and Construction of the Expression Vector}

The Psdl cDNA sequence (protein codifying DNA) was amplified by PCR (Polymerase Chain Reaction), using specific oligonucleotides (DNAgency), corresponding to the $\mathrm{N}$ - and C-terminal amino acid sequence of $P s \mathrm{~d} 1$ and Taq DNA polymerase (Gibco). The amplified 172-bp fragment, corresponding to the mature domain of $P s \mathrm{~d} 1$, was introduced into the commercial pGEM-T plasmid (Promega) to yield $\mathrm{r} P s \mathrm{~d} 1 / \mathrm{pGEM}-\mathrm{T}$. This plasmid was transformed into Escherichia coli (strain JM109) and the plasmidial DNA purified from transformant colonies was subjected to DNA sequence analysis, the results of which are shown in Figure 1. 


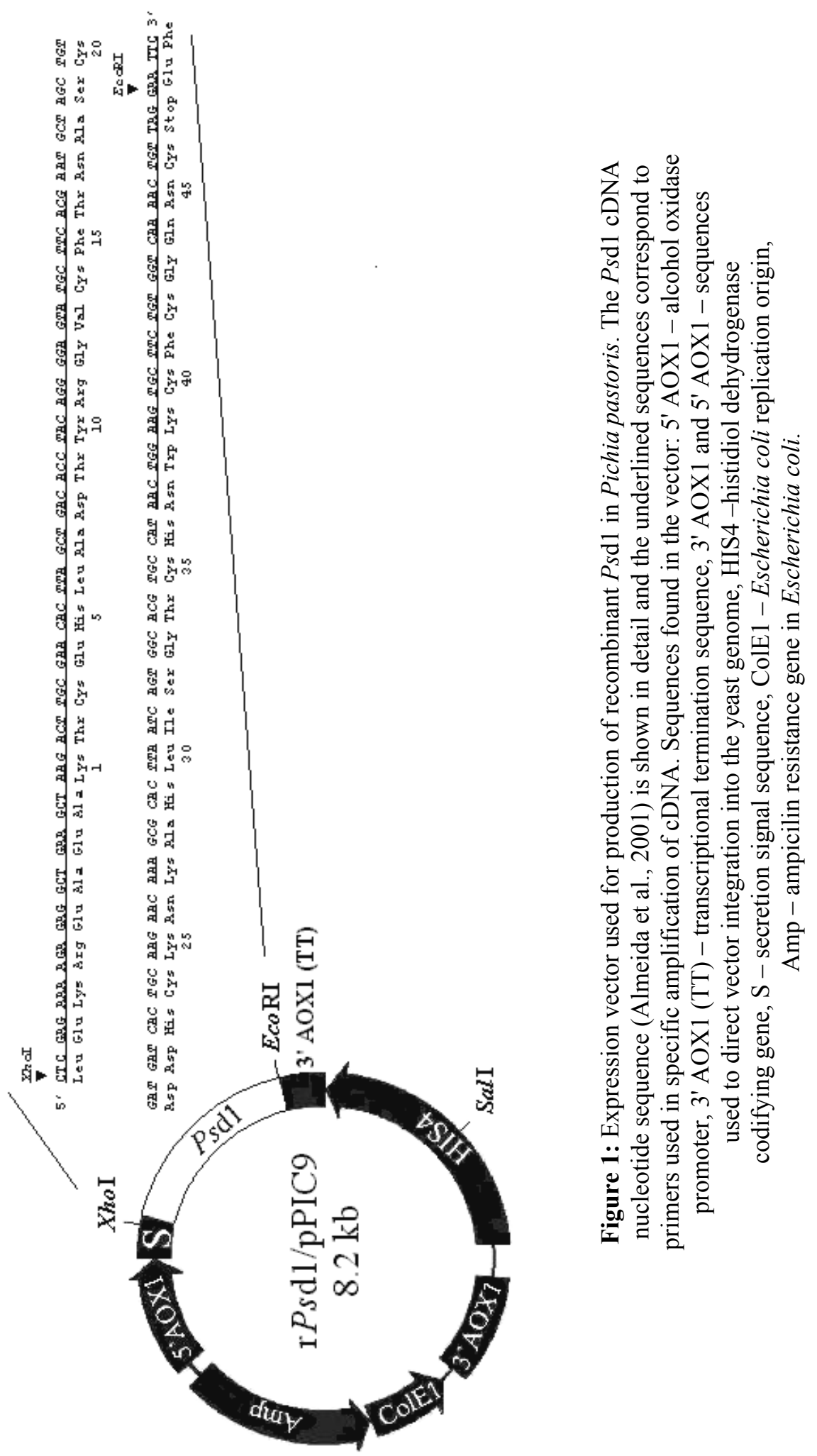


The plasmid $\mathrm{r} P s \mathrm{~d} 1 / \mathrm{pGEM}-\mathrm{T}$ was digested with XhoI and EcoRI restriction enzymes (Gibco) at restriction sites in the Psd1 cDNA fragment. This 172-bp fragment was purified by agarose gel electrophoresis and ligated to commercial expression plasmid for Pichia pastoris pPIC9 (Invitrogen), previously digested with XhoI and EcoRI. This approach allowed heterologous gene insertion between the 5' AOX1 promoter sequence and the transcription termination sequence. The resultant plasmid (rPsd1/pPIC9), shown in Figure 1, was transformed into Escherichia coli, enabling rPsd1 expression plasmid propagation.

Pichia pastoris (strain GS115) was transformed by the electroporation method with purified expression plasmids $\mathrm{r} P s \mathrm{~d} 1 / \mathrm{pPIC}$, previously linearized with SalI (Gibco), favoring vector integration at the HIS4 gene locus of the yeast genome and determining the $\mathrm{Mut}^{+}$ phenotype. The transformants were selected on medium lacking histidine, where only the plasmidcontaining cells are able to grow. The expression plasmids contain the histidiol dehydrogenase codifying gene HIS4, an essential enzyme for synthesis of histidine. The vector also contains the Saccharomyces cerevisiae $\alpha$-factor secretion signal fused to the heterologous gene in order to assure $\mathrm{r} P s \mathrm{~d} 1$ secretion. Details on the cloning and construction of the expression vector are presented in Almeida et al. (2001).

\section{Inoculum Preparation}

Pichia pastoris cells were stored in the inoculum medium (described below) with 15\% (v/v) glycerol (Merck) at ${ }^{-} 70^{\circ} \mathrm{C}$ and were allowed to grow on sterile Petri dishes, containing 1\% glucose, 1.34\% YNB without amino acids (Yeast Nitrogen Base: 74.5\% $\mathrm{w} / \mathrm{w}\left(\mathrm{NH}_{4}\right)_{2} \mathrm{SO}_{4}, 14.7 \% \mathrm{w} / \mathrm{w} \quad \mathrm{KH}_{2} \mathrm{PO}_{4}, 7.5 \% \mathrm{w} / \mathrm{w}$ $\mathrm{MgSO}_{4}, 1.6 \% \mathrm{w} / \mathrm{w} \mathrm{CaCl}_{2}, 1.6 \% \mathrm{w} / \mathrm{w} \mathrm{NaCl}$ and $<0.1 \% \mathrm{w} / \mathrm{w}$ other minerals, Difco Laboratories), $4.10^{-}$ ${ }^{5} \%$ biotin (Merck) and $1.5 \%$ agar, at $30^{\circ} \mathrm{C}$ for 72 hours.

One colony was selected to produce the inoculum of both shaking flasks and bioreactor. The inoculum sterile medium contained $1.34 \%$ YNB without amino acids, $4.10^{-5} \%$ biotin and $100 \mathrm{mM}$ of potassium phosphate buffer $(\mathrm{pH}=6)$, supplemented with $1 \%$ glycerol. The recombinant yeast was cultured at $30^{\circ} \mathrm{C}$ until the exponential growth phase was achieved (about $\mathrm{Abs}_{600 \mathrm{~nm}}=4$ ). Cells from this inoculum were harvested by centrifugation.

\section{Fed-Batch Cultivation}

The centrifuged cells were resuspended in the sterile medium described above, and supplemented with $0.5 \%$ methanol (Merck) instead of $1 \%$ glycerol, in order to achieve an $\mathrm{Abs}_{600 \mathrm{~nm}}=1$. Secretion of the recombinant $P s \mathrm{~d} 1$ was induced by methanol as the yeast carbon source. Target protein was expressed in a $500 \mathrm{~mL}$ shaking flask with a medium volume of 50 $\mathrm{mL}$ at $250 \mathrm{rpm}$, and also in a $2 \mathrm{~L}$ bioreactor with $1000 \mathrm{~mL}$ of medium at $500 \mathrm{rpm}$ and an air/medium volumetric rate of $1.5 \mathrm{vvm}$. Tween $80(0.1 \% \mathrm{v} / \mathrm{v})$ was added as an antifoam. The process was performed in fed-batch mode by adding an instantaneous pulse of $0.5 \%(\mathrm{v} / \mathrm{v})$ methanol every 24 $\mathrm{h}$. The whole experiment required about $100 \mathrm{~h}$ at a constant temperature of $30^{\circ} \mathrm{C}$.

In both shaking flasks and bioreactor, experiments were monitored every $12 \mathrm{~h}$ by $\mathrm{pH}$ analysis using Merck indicator strips, cell growth at $600 \mathrm{~nm}$ absorbance, and dissolved oxygen concentration with a polarographic electrode. In some shaking flasks experiments, $\mathrm{pH}$ was also controlled to hold it constant at $\mathrm{pH}=4$ and $\mathrm{pH}=6$.

The protein produced was quantified every $12 \mathrm{~h}$ by reverse-phase HPLC in a C8 column (Vydac, $10 \mathrm{x}$ $250 \mathrm{~mm})$ with a linear gradient elution $(22.5 \%$ to $35 \% \mathrm{v} / \mathrm{v}$ ) of acetonitrile (Merck) in $0.1 \%$ TFA (Sigma) at a flow rate of $4 \mathrm{~mL} / \mathrm{min}$. The eluant was monitored by absorbance $(214 \mathrm{~nm})$ and fluorescence (280 $\mathrm{nm}$ excitation and $340 \mathrm{~nm}$ emission).

\section{Antifungal Assays}

Antifungal assays were carried out by microspectrophotometry. Routinely, tests were performed with $20 \mathrm{~mL}$ of the filter-sterilized putative antimicrobial peptide in water and $100 \mathrm{~mL}$ of the test fungal spore suspension $\left(3.10^{4}\right.$ spores $\left./ \mathrm{mL}\right)$ in potato dextrose (Difco Laboratories). Controls were tested identically except that the peptide was omitted. Cultures were incubated at $25^{\circ} \mathrm{C}$ until the absorbance at $540 \mathrm{~nm}$ indicated that $50 \%$ of maximum fungal growth has been attained, based on the growth curve for each microorganism tested. Percentage growth inhibition is defined as 100 times the ratio of the corrected absorbance at $540 \mathrm{~nm}$ of the control microculture, minus the corrected absorbance of the test microculture, divided by the corrected absorbance of the control microculture. Other Psd1 antifungal activities can be found in Almeida et al. (2000).

\section{Bioprocess Modeling}

$\mathrm{r} P s \mathrm{~d} 1$ expression in Pichia pastoris was modeled using an unstructured growing Monod-type model, as described by Equations (1) and (2). 


$$
\begin{aligned}
& \frac{\mathrm{dX}}{\mathrm{dt}}=\left(\mu_{\mathrm{x}, \max } \frac{\mathrm{DO}}{\left(\mathrm{K}_{\mathrm{DO}}+\mathrm{DO}\right)}-\mathrm{K}_{\mathrm{d}}\right) \mathrm{X} \\
& \frac{\mathrm{dP}}{\mathrm{dt}}=\alpha \frac{\mathrm{dX}}{\mathrm{dt}}
\end{aligned}
$$

Dissolved oxygen was chosen as the limiting nutrient because Pichia pastoris is considered a strictly aerobic yeast and methanol consumption is directly associated with oxygen depletion. Cell death was incorporated into the model with the $\mathrm{K}_{\mathrm{d}}$ parameter. Protein production was considered to be totally associated with cell growth by the $\alpha$ parameter. This assumption is based on the experimental observation that concentration of secreted proteins in the medium is roughly proportional to cell concentration (Cereghino and Cregg, 2000).

In order to analyze the results obtained under different process conditions, protein productivity and yield per cell unit were calculated according to Equations (3) and (4), using experimental data up to 84 hours.

$$
\begin{aligned}
& \text { productivity }=\left.\frac{\Delta \mathrm{P}}{\Delta \mathrm{t}}\right|_{0} ^{84} \\
& \text { yield }=\left.\frac{\Delta \mathrm{P}}{\Delta \mathrm{X}}\right|_{0} ^{84}
\end{aligned}
$$

$\mu_{\mathrm{x}, \max }, \mathrm{K}_{\mathrm{DO}}, \mathrm{K}_{\mathrm{d}}$ and $\alpha$ were estimated with the help of MATLAB Optimization Toolbox (The Mathworks Inc.) by minimization of quadratic residuals between the experimental and model data, according to the objective function shown in Equation (5), using the Simplex - Nelder \& Mead search method. Experimental errors associated with cell and protein concentrations were estimated at $10 \%$, through replication of the monitored $\mathrm{pH}$ experiment performed in the shaker. Statistical significance of estimated parameters was determined by the $t$-test at a $95 \%$ confidence level.

$$
\left.\underset{\mu_{\mathrm{x}, \max }, \mathrm{K}_{\mathrm{DO}}, \mathrm{K}_{\mathrm{d}}, \alpha}{\operatorname{Minimize}} \sum_{\mathrm{i}}^{\mathrm{ne}} \sum_{\mathrm{j}}^{\mathrm{np}}[\mathrm{X}]_{\exp }-[\mathrm{X}]_{\bmod }\right)^{2}+\left([\mathrm{P}]_{\exp }-[\mathrm{P}]_{\bmod }\right)^{2}
$$

\section{RESULTS AND DISCUSSION}

The expression system used to produce $\mathrm{r} P s \mathrm{~d} 1$ by growing Pichia pastoris in methanol was considered efficient, achieving protein concentrations from 4 to $8 \mathrm{mg} / \mathrm{L}$, depending on the process conditions evaluated. Experiments carried out at different $\mathrm{pHs}$ and under different volume conditions obtained similar yeast growing results, up to 6 (mg dry cells)/mL, with the exception of the experiment conducted at $\mathrm{pH} 4$, in which only half of that concentration was obtained. Under all conditions the concentration of dissolved oxygen measured was similar, varying from 8 to $2 \mathrm{ppm}$.

Expression results were applied to the modeling process using the Monod-type model previously discussed in the Experimental Section. It was verified that all estimated parameters were statistically significant, attesting to the model's coherence in describing the bioprocess under study. Furthermore, the success of the modeling was measured and confirmed by objective function values.

\section{Effect of pH}

According to reports in the literature, Pichia pastoris is able to grow in a wide range of $\mathrm{pH}$ (from 3 to 7) with minimal effects on growth rate. However, this variable may affect protease activity and, as a consequence, protein secretion (Sreekrishna et al., 1997; Inan et al., 1999; Files et al., 2001). Based on this and on empirical modeling reported elsewhere (Larentis et al., 2001), three different $\mathrm{pH}$ conditions were tested in experiments carried out in shaking flasks. In the first experiment the variation in $\mathrm{pH}$ (from $\mathrm{pH}_{\text {initial }}=6$ to $\mathrm{pH}_{\text {final }}=4$ after $84 \mathrm{~h}$ ) caused by yeast growth and metabolism was only monitored. The other two tests were carried out by correcting the $\mathrm{pH}$ every $12 \mathrm{~h}$ in order to maintain $\mathrm{pH}$ values at 6 and 4, respectively. Since $\mathrm{pH}$ was not automatically controlled, an acidification of $0.5 \mathrm{pH}$ units was observed at every $12 \mathrm{~h}$ which was corrected by $\mathrm{NaOH}$ addition.

Figure 2 shows experimental and modeling results obtained at different $\mathrm{pHs}$. Parameter estimation results are reported in Table 1.

Analysis of estimated parameters reveals that controlling $\mathrm{pH}$ (at $\mathrm{pH} 4$ and 6) leads to a reduction in specific growth rate. This behavior goes along with reduction of $\mathrm{K}_{\mathrm{DO}}$ values and the maintenance of $\mathrm{K}_{\mathrm{d}}$ values, which shows that the levels of cell lysis are similar in all cases studied. A higher decrease in the $K_{D O}$ value indicates a higher affinity of the microorganism for dissolved oxygen and also greater efficiency in methanol metabolism.

Furthermore, a significant increase in the $\alpha$ value in the experiment conducted at $\mathrm{pH} 4$ was observed. Since this parameter is directly associated with product yield by cell unit, this result indicates that the process can be improved by carring out experiments at $\mathrm{pH} \mathrm{4,} \mathrm{even} \mathrm{though} \mathrm{faster} \mathrm{cell} \mathrm{growth}$ and higher productivity were observed in the experiment carried out with no $\mathrm{pH}$ control. 


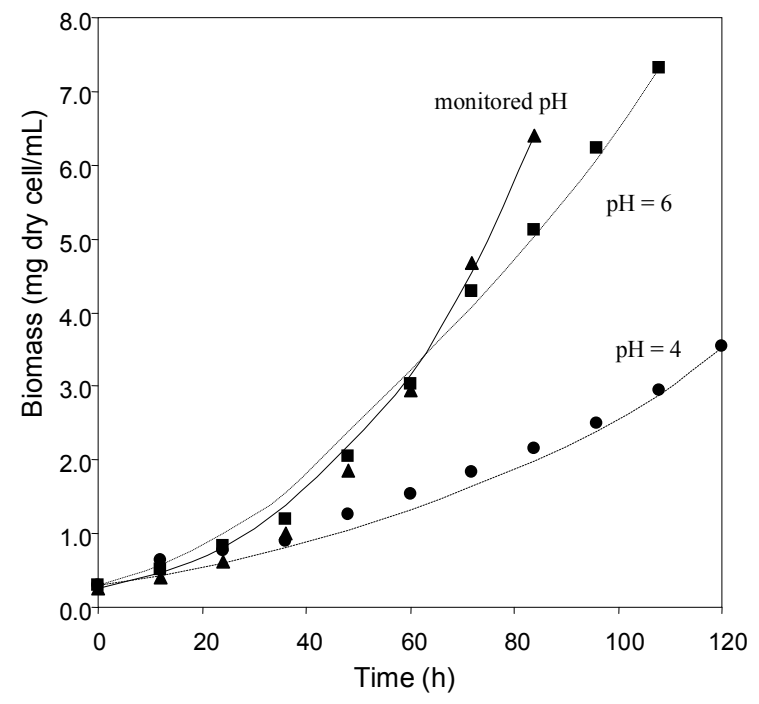

(a)

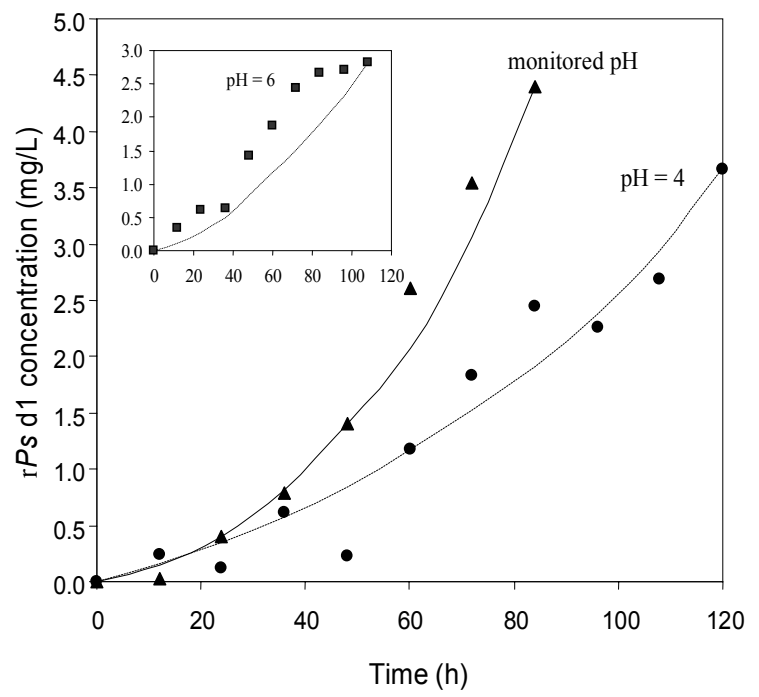

(b)

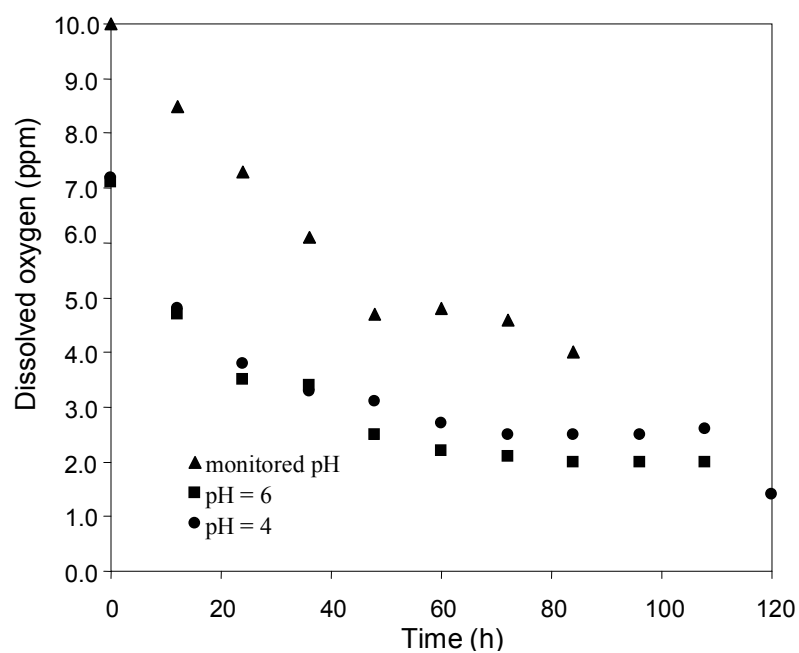

(c)

Figure 2: Biomass (A), $\mathrm{rPs} \mathrm{d} 1$ (B) and dissolved oxygen concentration (C) obtained in $50 \mathrm{~mL}$ at different $\mathrm{pHs}$. Experimental data (symbols) and model data (lines) for monitored $\mathrm{pH}(\boldsymbol{\wedge}$ and -$), \mathrm{pH}=6(\boldsymbol{\bullet}$ and ---$)$ and $\mathrm{pH}=$ $4(\bullet$ and --$)$. The inset in (B) corresponds to $\mathrm{r} P \mathrm{sd} 1$ concentration for $\mathrm{pH}=6$ in the same time scale.

Table 1: Estimated parameters and $84 \mathrm{~h}$ productivity and yield results, obtained for yeast growth in $50 \mathrm{~mL}$ in shaking flasks at different process $\mathrm{pHs}$.

\begin{tabular}{|l|c|c|c|}
\hline & Monitored $\mathbf{p H}$ & $\mathbf{p H}=\mathbf{6}$ & $\mathbf{p H}=\mathbf{4}$ \\
\hline$\mu_{\mathrm{x}, \max }\left(\mathrm{h}^{-1}\right)$ & 0.36 & 0.25 & 0.13 \\
$\mathrm{~K}_{\mathrm{DO}}(\mathrm{ppm})$ & 0.28 & 0.17 & 0.08 \\
$\mathrm{~K}_{\mathrm{d}}\left(\mathrm{h}^{-1}\right)$ & 0.65 & 0.63 & 0.71 \\
$\alpha(\mathrm{mg} \mathrm{rPsd} 1 / \mathrm{g}$ cells $)$ & 0.71 & 0.40 & 1.13 \\
productivity $\left(\mathrm{ppm} . \mathrm{h}^{-1}\right)$ & 0.05 & 0.03 & 0.03 \\
yield (mg rPsd1/g cells) & 0.71 & 0.55 & 1.32 \\
\hline
\end{tabular}




\section{Effect of Bioreactor Volume}

The scale-up from $50 \mathrm{~mL}$ in the shaking flask to $1000 \mathrm{~mL}$ in the bioreactor was carried out with a significant increase in the $\mathrm{r} P s \mathrm{~d} 1$ concentration produced by the recombinant yeast. The $\mathrm{r} P s \mathrm{~d} 1$ concentration obtained in bioreactor when the yeast stopped growing was $100 \%$ higher than that obtained in shaking flasks, while dissolved

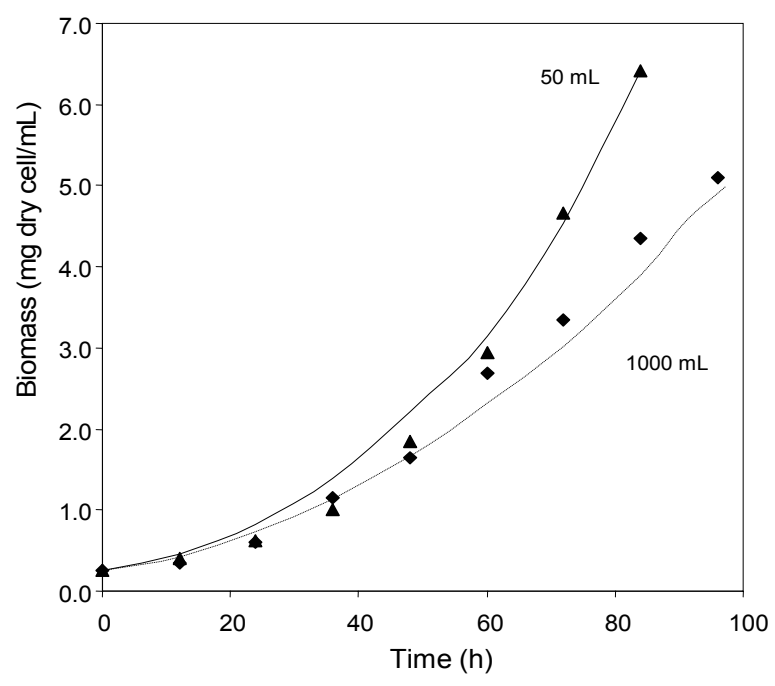

(a)

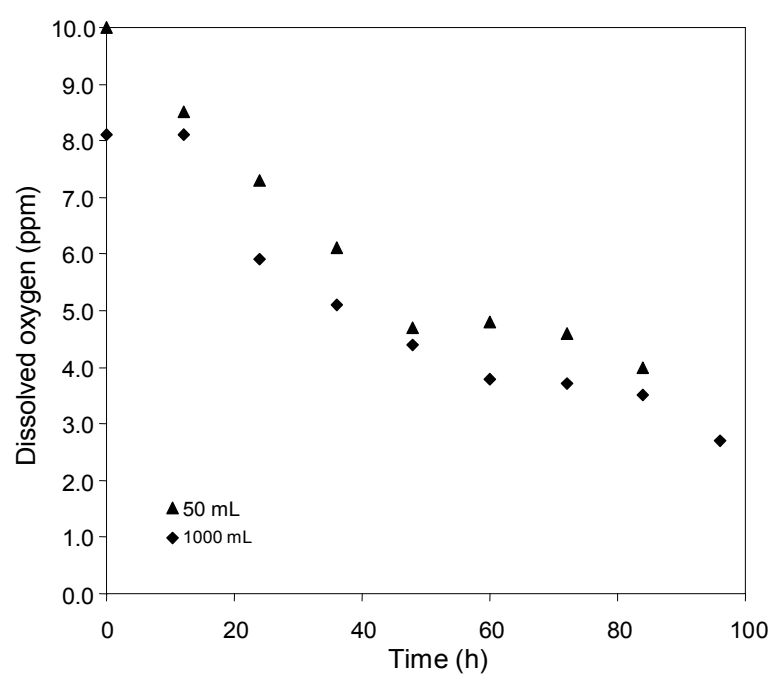

(c) oxygen consumption was quite similar in both cases. In these experiments $\mathrm{pH}$ was only monitored and a similar profile was observed. The best expression conditions were observed in the experiment carried out in the bioreactor after 80 to $100 \mathrm{~h}$, yielding around $8 \mathrm{mg} / \mathrm{L}$ of $\mathrm{r} P s \mathrm{~d} 1$. Experimental and modeling data are presented in Figure 3 and parameter estimation results are shown in Table 2 .

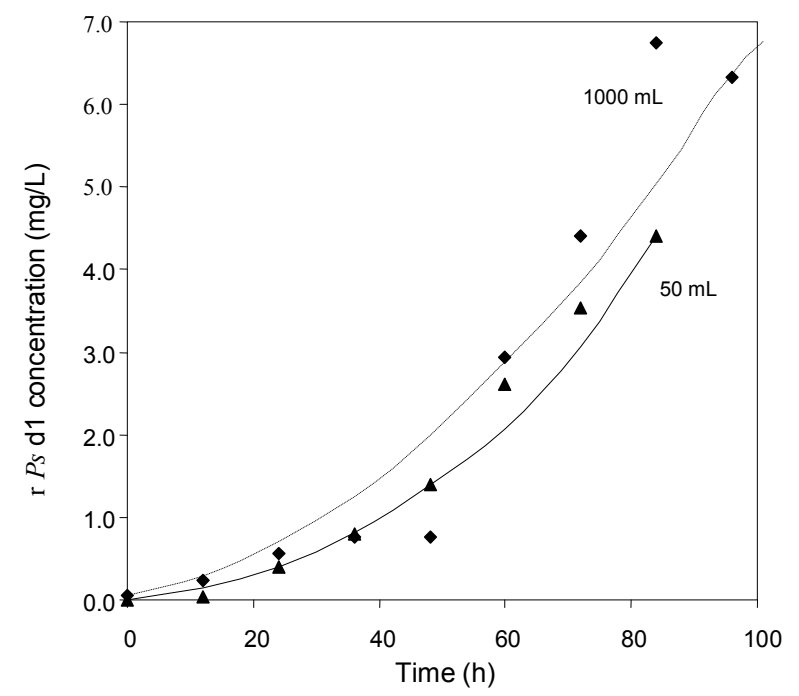

(b)

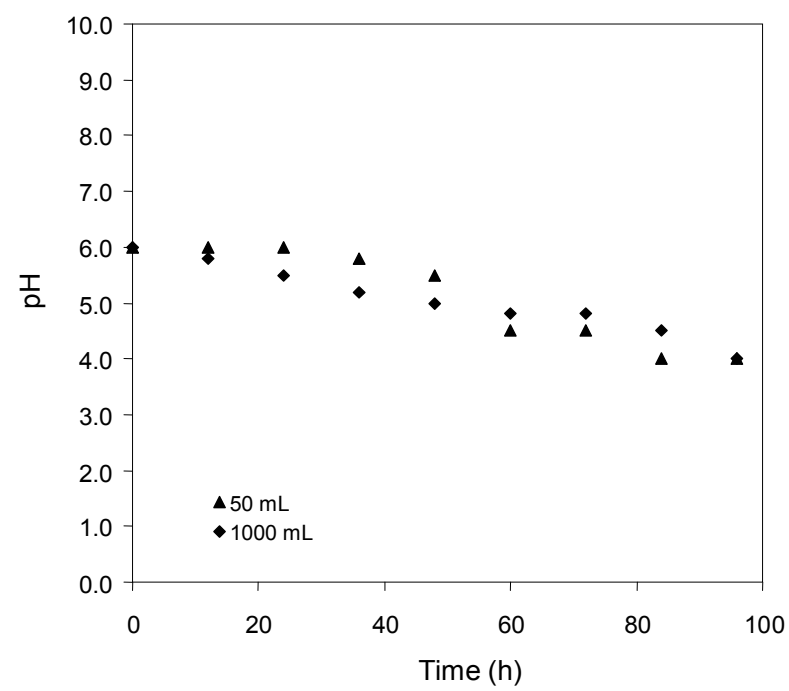

(d)

Figure 3: Recombinant Pichia pastoris biomass (A), $\mathrm{r} P \mathrm{~s} \mathrm{~d} 1$ (B), dissolved oxygen concentration (C) and $\mathrm{pH}$ variation (D) obtained in different volumes. Experimental data (symbols) and model data (lines) for $50 \mathrm{~mL}(\boldsymbol{\Lambda}$ and - ) and $1000 \mathrm{~mL}(\bullet$ and ---$)$. 
Table 2: Estimated parameters and $84 \mathrm{~h}$ productivity and yield results, obtained for yeast growth with monitored $\mathrm{pH}$ and different process scales.

\begin{tabular}{|l|c|c|}
\hline & $\begin{array}{c}\text { Shaking flask } \\
(50 \mathrm{~mL})\end{array}$ & $\begin{array}{c}\text { Bioreactor } \\
(1000 \mathrm{~mL})\end{array}$ \\
\hline$\mu_{\mathrm{x}, \max }\left(\mathrm{h}^{-1}\right)$ & 0.36 & 0.27 \\
$\mathrm{~K}_{\mathrm{DO}}(\mathrm{ppm})$ & 0.28 & 0.20 \\
$\mathrm{~K}_{\mathrm{d}}\left(\mathrm{h}^{-1}\right)$ & 0.65 & 0.81 \\
$\alpha(\mathrm{mg} \mathrm{rPsd} 1 / \mathrm{g}$ cells $)$ & 0.71 & 1.38 \\
productivity $\left(\mathrm{ppm} . \mathrm{h}^{-1}\right)$ & 0.05 & 0.08 \\
yield $(\mathrm{mg} \mathrm{rPsd} 1 / \mathrm{g}$ cells $)$ & 0.71 & 1.63 \\
\hline
\end{tabular}

Parameter estimation showed that, although the cells grew at a lower rate in the bioreactor (lower $\mu_{\mathrm{x}, \max }$ and higher $\mathrm{K}_{\mathrm{d}}$ ), $\alpha$ was significantly enhanced in the bioreactor (approximately twofold) probably due to the greater utilization of oxygen (lower $\mathrm{K}_{\mathrm{DO}}$ value), leading to a higher protein yield by cell mass.

Results also show that in the same period (84 hours), the productivity achieved in the bioreactor was higher than that achieved in the shaking flask. This behavior could be explained by the differences on aeration systems: oxygen diffusion is superficial in shaking flasks while in bioreactors the employed mechanical system permits a higher retention time of the gas in contact to the liquid phase. The importance of a better oxygenation of the system is expressed by the strictly aerobic metabolism of the yeast used in this work.

\section{Antifungal Activity}

Recombinant defensin was sequenced and characterized structurally and was found to be very similar to native defensin (Almeida et al., 2001). Antifungal activity shown by the recombinant protein in the inhibition of Fusarium solani and Neurospora crassa has a profile similar to that of native $P s \mathrm{~d} 1$. These results are presented in Figure 4.

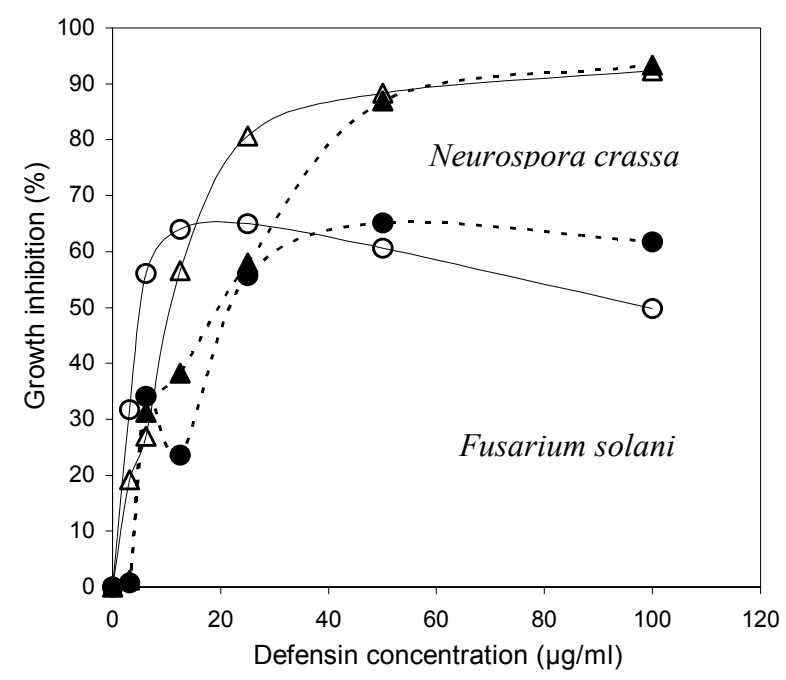

Figure 4: Comparison of growth inhibition activities for $\mathrm{r} P s \mathrm{~d} 1$ produced in Pichia pastoris (solid symbols) and native $P S \mathrm{~d} 1$ (empty symbols) against Fusarium solani $(\bullet$ and $\circ$ ) and Neurospora crassa

( $\triangle$ and $\triangle$ ) in potato dextrose medium (average error about $10 \%$ ). 


\section{CONCLUSIONS}

According to the data presented, 4 to $8 \mathrm{mg} / \mathrm{L}$ of biologically active $\mathrm{rPsd} 1$ were obtained. The recombinant protein had a structure and a level of antifungal activity very similar to those of native defensin. This enabled us to confirm that Pichia pastoris is an efficient heterologous host for protein production.

The modeling of this system allowed analysis of the effects of $\mathrm{pH}$ and scale-up on yeast growth and protein production. Control of $\mathrm{pH}$ led to a decrease in specific growth rate, and protein secretion by the cell unit was enhanced in the experiment carried out at $\mathrm{pH} 4$.

The use of a bioreactor improved $\mathrm{r} P \mathrm{sd} 1$ concentration, probably due to better oxygenation in the medium. Also, a lower cell concentration was obtained in bioreactor with similar dissolved oxygen profile when compared to shaking flasks at same $\mathrm{pH}$ condition. It means that protein production was enhanced by a better utilization of the oxygen available per cell mass unit.

This results indicate that the production of $\mathrm{r} P s \mathrm{~d} 1$ can be increased by conducting an experiment at $\mathrm{pH}$ $=4$ in a bioreactor under conditions of slower growth and more efficient oxygenation.

\section{NOMENCLATURE}

DO dissolved oxygen concentration (ppm)

$\mathrm{K}_{\mathrm{d}} \quad$ cell death constant $\left(\mathrm{h}^{-1}\right)$

$\mathrm{K}_{\mathrm{DO}}$ model constant related to dissolved oxygen (ppm)

ne number of experiments

$\mathrm{np}$ number of parameters

$\mathrm{P} \quad$ protein concentration ( $\mathrm{mg} \mathrm{rPsd} / \mathrm{L})$

$\mathrm{t}$ time of induction (h)

$\mathrm{X}$ biomass concentration ( $\mathrm{mg}$ dry cells $/ \mathrm{mL}$ )

\section{Greek Letters}

$\alpha \quad$ protein production by cell unit (mg $\mathrm{rPsd} 1 / \mathrm{g}$ dry cells)

$\Delta \mathrm{P} \quad$ variation in protein concentration $(\mathrm{mg}$ rPsd1/L)

$\Delta \mathrm{t} \quad$ period of time (h)

$\Delta \mathrm{X} \quad$ variation in biomass concentration (mg dry cells/mL)

$\mu \quad$ specific cell growth rate $\left(\mathrm{h}^{-1}\right)$

$\mu_{\mathrm{x}, \max }$ maximum specific cell growth rate considering dissolved oxygen as limiting substrate $\left(\mathrm{h}^{-1}\right)$

\section{Subscripts}

exp experimental

mod model

\section{ACKNOWLEDGEMENTS}

CNPq (Conselho Nacional de Desenvolvimento Científico e Tecnológico), FAPERJ (Fundação Carlos Chagas Filho de Amparo à Pesquisa do Estado do Rio de Janeiro) and FUJB (Fundação José Bonifácio) supported this work.

\section{REFERENCES}

Almeida, M.S., Cabral, K.M.S., Zingali, R.B. and Kurtenbach, E., Characterization of Two Novel Defense Peptides from Pea (Pisum sativum) Seeds. Arch. Biochem. Biophys., vol. 378, p. 278 (2000).

Almeida, M.S., Cabral, K.S., Medeiros, L.N., Valente, A.P., Almeida, F.C.L. and Kurtenbach, E., cDNA Cloning and Heterologous Expression of Functional Cysteine-rich Antifungal Protein Psd1 in the Yeast Pichia pastoris. Arch. Biochem. Biophys., vol. 395, p. 199 (2001).

Boze, H., Laborde, C., Chemardin, P., Richard, F., Venturin, C., Combarnous, Y. and Moulin, G., High-level Secretory Production of Recombinant Porcine Follicle-stimulating Hormone by Pichia pastoris. Process Biochem., vol. 36, p. 907 (2001).

Brierley, R.A., Bussineau, C., Kosson, R., Melton, A. and Siegel, R.S., Fermentation Development of Recombinant Pichia pastoris Expressing the Heterologous Gene: Bovine Lysozyme. Ann. NY Acad. Sci., vol. 589, p. 350 (1990).

Cereghino, J.L. and Cregg, J.M. Heterologous Protein Expression in the Methylotrophic Yeast Pichia pastoris. FEMS Microbiol. Rev., vol. 24, p. 45 (2000).

Chen, Y., Cino, J., Hart, G., Freedman, D., White, C. and Komives, E.A., High Protein Expression in Fermentation of Recombinant Pichia pastoris by a Fed-batch Process. Process Biochem., vol. 32, p. 107 (1997).

Chen, Y., Jin, M., Egborge, T., Coppola, G., Andre, J. and Calhoun, D.H., Expression and Characterization of Glycosylated and Catalytically Active Recombinant Human $\alpha$ - 
galactosidase A Produced in Pichia pastoris. Protein Expr. Purif., vol. 20, p. 472 (2000).

Chiruvolu, V., Cregg, J.M. and Meagher, M.M., Recombinant Protein Production in an Alcohol Oxidase-defective Strain of Pichia pastoris in Fedbatch Fermentations. Enzyme Microb. Technol., vol. 21, p. 277 (1997).

Creeg, J.M., Tschopp, J.F., Stillman, C., Siegel, R., Akong, M., Craig, W.S., Buckholz, R.G., Madden, K.R., Kellaris, P.A., Davis, G.R., Smiley, B.L., Cruze, J., Torregrossa, R., Velicebeli, G. and Thill, G.P., High-level Expression and Efficient Assembly of Hepatitis B Surface Antigen in the Methylotrophic Yeast, Pichia pastoris. Bio/Technology, vol. 5, p. 47 (1987).

Files, D., Ogawa, M., Scaman, C.H. and Baldwin, S.A., A Pichia pastoris Fermentation Process for Producing High-levels of Recombinant Human Cystatin-C. Enzyme Microb. Technol., vol. 29, p. 335 (2001).

Inan, M., Chiruvolu, V., Eskridge, K.M., Vlasuk, G.P., Dickerson, K., Brown, S. and Meagher, M.M., Optimization of Temperature - Glycerol $\mathrm{pH}$ Conditions for a Fed-batch Fermentation Process for Recombinant Hookworm (Ancylostoma caninum) Anticoagulant Peptide (AcAP-5) Production by Pichia pastoris. Enzyme Microb. Technol., vol. 24, p. 438 (1999).

Larentis, A.L, Almeida, M.S., Cabral, K.M.S., Coelho, M.A.Z. and Kurtenbach, E., Fermentor
Expression of the Recombinant Pisum Sativum Defensin 1 ( $\mathrm{r} P s \mathrm{~d} 1)$ in Pichia Pastoris. XXX Annual Meeting of Brazilian Society of Biochemistry and Molecular Biology - SBBq, Caxambu, Brazil (2001).

Minning, S., Serrano, A., Ferrer, P., Solá, C., Schmid, R.D. and Valero, F., Optimization of the High-level Production of Rhizopus oryzae Lipase in Pichia pastoris. J. Biotechnol., vol. 86, p. 59 (2001).

Payne, M.S., Petrillo, K.L., Gavagan, J.E., Wagner, L.W., Dicosimo, R. and Anton D.L., High-level Production of Spinach Glycolate Oxidase in the Methylotrophic Yeast Pichia pastoris: Engineering a Biocatalyst. Gene, vol. 167, p. 215 (1995).

Payne, M.S., Petrillo, K.L., Gavagan, J.E., Dicosimo, R., Wagner, L.W. and Anton D.L. Engineering Pichia pastoris for Biocatalysis: Co-production of Two Active Enzymes. Gene, vol. 194, p. 179 (1997).

Romanos, M., Advances in the Use of Pichia pastoris for High-level Gene Expression. Curr. Opin. Biotechnol., vol. 6, p. 527 (1995).

Sreekrishna, K., Brankamp, R.G., Kropp, K.E., Blankenship, D.T., Tsay, J-T., Smith, P.L., Wierschke, J.D., Subramaniam, A. and Birkenberger, L.A., Strategies for Optimal Synthesis and Secretion of Heterologous Proteins in the Methylotrophic Yeast Pichia pastoris. Gene, vol. 190, p. 55 (1997). 